\title{
Gastroprotective Effect of Carrot (Daucus carota L.) Juice in Rat Models
}

\author{
Wong Hui Jiin ${ }^{1}$, Eva M. Hidayat ${ }^{2}$, Kiki Lukman ${ }^{3}$ \\ ${ }^{1}$ Faculty of Medicine, Universitas Padjadjaran, ${ }^{2}$ Department of Pharmacology and Therapy, Faculty \\ of Medicine, Universitas Padjadjaran, ${ }^{3}$ Department of Surgery, Division of Digestive Surgery, Faculty \\ of Medicine, Universitas Padjadjaran/ Dr. Hasan Sadikin General Hospital, Bandung, Indonesia
}

\begin{abstract}
Background: Gastritis has become one of the very common gastrointestinal tract disorders in clinical practice. One of the factors causing gastritis is the prolonged intake of nonsteroidal anti-inflammatory drugs (NSAIDs) which is commonly adopted by people suffering pain. The NSAIDs such as aspirin cause loss of mucosal integrity resulting in gastric mucosa inflamation. Carrot (Daucus carota L.) has long been used as a traditional medicine for various ailments. The presence of flavonoids and carotenoids in carrot is associated with gastroprotective effect.

Methods: The present study was undertaken to determine the gastroprotective effect of $4.08 \mathrm{~g}$ carrot juice administered by feeding tube on the hydrochloric acid (HCL) concentration in the stomach in aspirin-induced Wistar-strain rats. This was a laboratory experimental study performed at the Pharmacology Laboratory Faculty of Medicine Universitas Padjadjaran, Bandung Indonesia in October 2012. The parameter used HCL Concentration determined by titration method.

Results: The result of carrot juice consumption together with aspirin shows a statistically significant reduction in HCL concentration in the stomach $(\mathrm{p}<0.05)$. The result was also significant when compared with another medication, Misoprostol.

Conclusion: Carrot juice extract possesses gastroprotective effect when consumed with aspirin and thus support the use of carrot as an alternative treatment. [AMJ.2014;1(1):35-9]
\end{abstract}

Keywords: Aspirin, Carrot juice extract, gastroprotective, HCL concentration

\section{Efek Perlindungan Lambung dengan Jus Wortel (Daucus carota L.) pada Tikus}

\section{Abstrak}

Latar belakang: Gastritis merupakan salah satu kelainan pada saluran pencernaan yang sering ditemui. Salah satu penyebab dari gastritis adalah pemakaian nonsteroidal anti-inflammatory drugs (NSAIDs) dalam waktu lama dan biasanya digunakan oleh orang yang menderita sakit. Obat-obatan NSAID seperti aspirin dapat menyebabkan integritas mukosa menghilang dan terjadinya inflamasi pada mukosa lambung. Wortel (Daucus carota L.) merupakan tanaman tradisional yang sudah banyak digunakan untuk berbagai macam penyakit. Flavonoid dan carotenoid yang ada pada wortel memiliki efek perlindungan terhadap lambung.

Metode: Penelitian dilakukan untuk menentukan efek perlindungan lambung dengan jus wortel pada konsentrasi HCL dalam lambung tikus yang diinduksi dengan aspirin. Penelitian ini merupakan suatu studi eksperimental yang dilakukan di Laboratorium Farmakologi Fakultas Kedokteran Universitas Padjadjaran, Bandung, Indonesia pada bulan Oktober 2012. Parameter yang digunakan adalah konsentrasi HCL yang ditentukan dengan metode titrasi.

Hasil: Hasil dari penggunaan jus wortel bersama dengan aspirin menunjukkan penurunan konsentrasi HCL yang signifikan pada lambung $(\mathrm{p}<0.05)$. Hasil ini juga signifikan bila dibandingkan dengan medikasi lain yaitu, Misoprostol.

Simpulan: Ekstrak jus wortel memiliki efek perlindungan lambung ketika digunakan dengan aspirin dan hal ini mendukung wortel sebagai pengobatan alternatif.

Kata kunci: Aspirin, jus wortel, efek perlindungan lambung, konsentrasi HCL

Correspondence: Wong Hui Jiin, Faculty of Medicine, Universitas Padjadjaran, Jalan Raya Bandung-Sumedang Km.21, Jatinangor, Sumedang, Indonesia, Phone: +628170209121, Email: hui_jiin88@yahoo.com 


\section{Introduction}

Gastritis is defined as an inflammatory disorder in the gastric mucosa layer. The etiological factors include Helicobacter pylori infection, prolonged intake of non-steroidal antiinflammatory drugs (NSAIDs) and excessive use of irritant to stomach such as alcohol. ${ }^{1}$ NSAIDs-associated gastrointestinal side effects are still high in community. ${ }^{2}$ Treatment with modern drugs such as prostaglandin analog, for example Misoprostol, is often prescribed for NSAIDs-related gastric injury. However, the medication gives relieves to the gastritis but produces several adverse effects. ${ }^{3}$

According to the World Health Organization (WHO) in 1980, in spite of the numerous adverse effects, research on medicinal plants is highly recommended in a condition where there is a lack of safe synthetic drugs. ${ }^{4}$ Carrot, which is also known as Daucus carota L., contains active ingredients necessary to maintain health. ${ }^{5}$ Carrot has high nutritional values such as for Vitamin A, B, C, D, E, potassium, copper, folic acid, magnesium, flavonoids, and carotene. ${ }^{6}$

The present study was undertaken to determine the gastroprotective effect of carrot juice on the hydrochloric acid (HCL) concentration in the stomach and to compare the effect to that of Misoprostol in aspirininduced rats.

\section{Methods}

Carrots were purchased from the local market in Jatinangor, Indonesia. The carrots used were cultivated in Lembang, Indonesia. Carrots were identified before the study by Drs. Joko Kusmoro, M.P, a Taxonomist, from Biology Department of Universitas Padjadjaran (UNPAD).

The part of the carrot used for this study was the taproot. First, the fresh taproots were washed, cut into small pieces, and then blended without adding water. ${ }^{7}$ Then the homogenized taproots were filtered, and the pulps were removed. Only the juice obtained was used for the experiment.

Subjects in this study consisted of 24 male rats (Rattus norvegicus), Wistar-strain, age 7-8 weeks, with a body weight between 200-250 grams. The rats had 7 days adaptation prior to the study at the Pharmacology Laboratory Faculty of Medicine Universitas Padjadjaran, Bandung Indonesia. Rats were fed on standard rodent pellets diet with water given ad libitum.

After the adaptation period, the rats were randomly put into 4 groups. Each group consisted of 6 rats. All groups were given different interventions except for the food and water which were standardized. The experiment was performed for 7 days. The ethical clearance was obtained from the Health Research Ethics Committee of the Faculty of Medicine, Universitas Padjadjaran (197/UN6. C2.1.2/KEPK/2012).

The design of the study was Laboratory

\section{Table 1 Experimental Groups}

\begin{tabular}{ll}
\hline \multicolumn{1}{c}{ Group } & \multicolumn{1}{c}{ Food and Drink Composition } \\
\hline Group 1 (control negative) & Standard food and water (ad libitum) + aspirin (90 mg) \\
Group 2 (control positive) & Standard food and water (ad libitum) + aspirin (90 mg) + carrot juice (4.08 g) \\
Group 3 (test group) & Standard food and water (ad libitum) + aspirin (90 mg) + Misoprostol \\
& $(0.0144 \mathrm{mg})$ \\
Group 4 (compare group) & Standard food and water (ad libitum) \\
\hline
\end{tabular}

Note: All treatments were given per oral using feeding tube 
Table 2 Mean HCL concentration (molar) by group

\begin{tabular}{|c|c|}
\hline & Parameter \\
\hline Group & $\begin{array}{c}\text { Concentration of HCL } \\
\text { (molar) }\end{array}$ \\
\hline 1 ( Negative control) & $0.0012 \pm 0.00028$ \\
\hline 2 ( Positive control) & $0.0011 \pm 0.00022$ \\
\hline 3 ( Test group) & $0.0005 \pm 0.00014 *$ \\
\hline 4 (Compare group) & $0.0006 \pm 0.00010 * \#$ \\
\hline
\end{tabular}

Note: Values are shown as the mean \pm SD

$* \mathrm{P}<0.05$ compared with positive control group

\# $\mathrm{P}<0.05$ compared with test group

Experimental with Complete Random Sampling. The study was undertaken to determine the gastroprotective effect of carrot juice on hydrochloric acid (HCL) concentration in the stomach and to compare the effect with that of Misoprostol in aspirininduced rats.

After 7 days of experiment, all the rats underwent fasting for 18 hours. On day 8, all rats were given anesthesia using diethyl ether and later they were sacrificed. The abdomen of the rat was opened to seek for the stomach and the edges. The edge of the stomach, pylorus and esophagus were all tied and the stomach was removed.

The stomach was washed with normal saline, dried, and later opened through the greater curvature. ${ }^{8}$ The stomach content was collected and centrifuged for 20 minutes at the speed of $3000 \mathrm{rpm}$. Later, $1 \mathrm{ml}$ of the supernatant fluid was taken carefully and diluted with $10 \mathrm{ml}$ of aqueous solution (ratio of 1:10). The concentration of HCL was confirmed using the titration method.

One $\mathrm{ml}$ of supernatant fluid was diluted with $10 \mathrm{ml}$ aqueous solution and then mixed well and 3 drops of phenolphthalein were added as an indicator. Finally, it was titrated with $\mathrm{NaOH} 0.01 \mathrm{M}$ until the color started to change into pink. The amount of $\mathrm{NaOH}$ used for the titration was counted to determine the concentration of HCL in the stomach of the rats. ${ }^{8}$

The statistical test used in this study was Independent Sample T-test. The test was performed with $95 \%(\alpha=5 \%)$ confidence. The hypothesis is accepted if $\mathrm{p}<0.05$.

This study takes place at the Pharmacology Laboratory Faculty of Medicine, Universitas Padjadjaran, Bandung Indonesia in the month of October 2012.

\section{Results}

Based on the results, Group 1 has the highest mean HCL concentration while the lowest mean HCL concentration was seen in Group 3 (Table 2).

The Independent Sample T-Test was used to investigate the mean concentration of

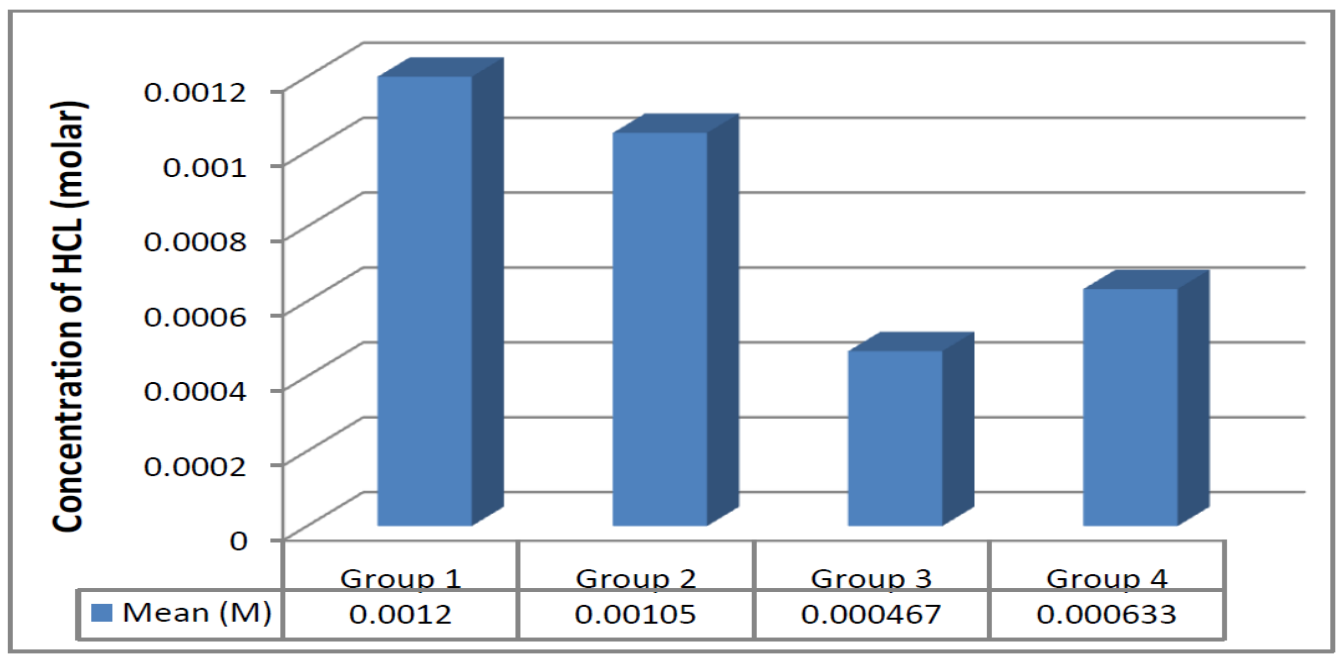

Figure 1 Mean HCL concentration in the stomach of rats by group. Group 3 and 4 shows a decrease in HCL concentration compared to group 2 . HCL, hydrochloric acid 
HCL between groups. The result shows no significant difference in HCL concentration between Group 1 and Group 2 ( $p>0.05$ ). In Group 3, the administration of aspirin and carrot juice together shows a significant decrease in HCL concentration in the stomach compared to that observed in the aspirin alone Group 2, $\mathrm{p}<0.05$. When compared, the administration of carrot juice (Group 3) and Misoprostol (Group 4) with aspirin presents a different result with carrot juice also shows a significant decrease. Co-administration of aspirin and Misoprostol (Group 4) shows a significant decrease when compared to aspirin alone (Group 2).

\section{Discussion}

Non-steroidal anti-inflammatory drugs (NSAIDs) such as aspirin, is known to induce inflammation in the gastric mucosa. Aspirin is a common medication taken by community to reduce pain. Aspirin works by inhibiting COX-1 and COX-2, which in turn will suppress the prostaglandin formation. In the stomach, prostaglandin plays an important role in defense and repair. Prostaglandin involves with increasing mucous and bicarbonate secretion, inhibiting stomach acid production, and increasing the blood flow to stomach wall. ${ }^{9}$ Therefore, the imbalance between the aggravating factors, NSAIDs, and maintenance of mucosal integrity, the prostaglandin, resulting in gastritis. (has no verb)

In this study, Group 2 (positive control) which was induced with aspirin did not show any increase in the HCL concentration compared to Group 1. This is because the parameter used here was the concentration of HCL. Administration of aspirin inhibits the prostaglandin. When prostaglandin decreases, bicarbonate secretion also decreases. However, the amount (n) of hydrogen ion secreted is not affected even though the bicarbonate decreases. So, when amount of hydrogen ion is same, provided the volume is same, the concentration will not change. Therefore, in the aspirin-induced group, it explains the reason why the concentration of HCL was not affected.

Carrot (Daucus carota L.) is one of the very popular vegetable and well known for its health benefits in the community. In the present study, it was observed that carrot triggers significant reduction in HCL concentration in aspirin-induced rat model. The presence of flavonoids in carrot that reduces the gastric acidity may be due to two factors, $\mathrm{H}+$ secretion inhibition and increase of prostaglandin formation. ${ }^{10}$ Therefore when prostaglandin increases, it stimulates secretion of mucous and bicarbonate, maintains the mucosal blood flow and also mucosal cell turnover and repair. ${ }^{7}$ The increase (or excess?) of bicarbonate binds to the free acid which neutralizes the acid generated by parietal cell and thus resulting in decrease of acid concentration in aspirininduced. The inhibition of $\mathrm{H}^{+}$also promotes further decrease in acid concentration. An alkaline $\mathrm{pH}$ in the surrounding environment of the stomach is important to restore a damaged region (restitution). ${ }^{9}$ Therefore, when acid concentration decreases, it is assumed that the gastric epithelial cells will heal. The presence of carotenoids in carrot (mostly $\beta$-carotene) which have anti-oxidant properties that are able to neutralize the free radical reactive oxygen molecules produced by the damaged mucosal cells. ${ }^{11}$

In this study, the effect of carrot juice extract is also compared to the use of Misoprostol. This is because carrot containing the flavonoids and carotenoids that have similar mechanisms of action as Misoprostol. Misoprostol is a synthetic analog of prostaglandin-1 (PGE1) which is used as the primary prevention for ulcer in those who are taking aspirin medication. ${ }^{9}$ Based on the statistical study, it is observed that Misoprostol has a significant difference $(p<0.05)$ compared to the control positive group and test group.

From the results, $4.08 \mathrm{~g}$ of carrot juice per day is suggested to have a gastroprotective effect in aspirin-induced rat model. This is statistically proven with a $p$-value $(p<0.05)$ between group 2 and group 3 that is significant. The gastroprotective effect in this study is only based on the measurement of HCL concentration in the stomach.

In conclusion, the results of this study shows that carrot (Daucus carota L.) juice extract able to lower down the HCL concentration in aspirininduced environment. Therefore, as reported, the presence of carotenoids, flavonoids, and other bioactive compounds in carrot may be associated with gastroprotective effect. Thus, this study supports the consumption of carrot juice extract as an alternative treatment for gastritis and prevention for ulceration induced by aspirin.

\section{References}

1. Johns Hopkins Medicine. Health Library on digestive disorder-gastritis. (Cited 2012 
November 26); Available from: http:// www.hopkinsmedicine.org/healthlibrary/ conditions/digestive_disorders / gastritis_85,P00371/.

2. Lanas A, García-Rodríguez LA, Arroyo MT, Bujanda L, Gomollón F, Forne M, et al. Effect of antisecretory drugs and nitrates on the risk of ulcer bleeding associated with nonsteroidal anti-inflammatory drugs, antiplatelet agents, and anticoagulants. Am J Gastroenterol. 2007;102(3):507-15.

3. Harvey RA, Champe PC, editors. Pharmacology. $2^{\text {nd }}$ ed. Philadelphia: Lippincott Williams \& Wilkins; 2000.p. 235-41

4. Eisenberg DM, Kessler RC, Foster C, Norlock FE, Calkins DR, Delbanco TL. Unconventional medicine in the United States: Prevalence,costs and patterns of use. N Engl J Med. 1993;328(4):246-52.

5. World Health Organization. WHO's Fact sheet No. 134: traditional medicine. Geneva:WHO; 2003.

6. United States Department of Agriculture. USDA national nutrient database for standard reference, release 25. Washington
DC: USDA's Agricultural Service; 2012.

7. Khatib N, Angel G, Nayna H, Kumar JR. Gastroprotective activity of the aqueous extract from the roots of daucus carota in rats. IJRAP. 2010;1(1):112-9.

8. John TA, Onabanjo AO. Effect of an aqueous extract of entandrophragma utile bark on gastric acid secretion in rat and isolated ileum contractility in guinea pig. Afr J Biomed Res. 2010;13(3):197-206.

9. Valle JD. Principles of Internal Medicine. In: Fauci AS, Kasper DL, Longo DL, Braunwald E, Hauser SL, Jameson JL, et al., editors. $17^{\text {th }}$ ed. New York: McGraw-Hill; 2008. p. 1855-70.

10. Gálvez J, De Medina FS, Jiménez J, Zarzuelo A. Effects of flavonoids on gastrointestinal disorders. Studies in Natural Products Chemistry. 2001;25(F):607-49.

11. Amarowicz R, Pegg RB, Moghaddam PR, Barl B, Weil JA. Free-radical scavenging capacity and antioxidant activity of selected plant species from the Canadian prairies. Food Chemistry. 2004;84(4):55162. 